\title{
Going extinct before being discovered? New lichen fungi from a small fragment of the vanishing Atlantic Rainforest in Brazil
}

\author{
Thamires Almeida Pereira', Paula de Oliveira Passos ${ }^{I}$, Lidiane Alves dos Santos ${ }^{I}$, Robert Lücking ${ }^{2 *}$ \& \\ Marcela Eugenia Da Silva Cáceres ${ }^{I}$ \\ ${ }^{1}$ Universidade Federal de Sergipe, Departamento de Biociências, CEP: 49500-000, Itabaiana, SE, Brazil \\ ${ }^{2}$ Botanischer Garten und Botanisches Museum, Freie Universität Berlin, Königin-Luise-Strasse 6-8, \\ D-14195 Berlin, Germany \\ *Corresponding author: Robert Lücking, e-mail: r.luecking@bgbm.org
}

PEREIRA, T.A., PASSOS, P.O., SANTOS, L.A., LÜCKING, R. \& CÁCERES, M.E.S. Going extinct before being discovered? New lichen fungi from the vanishing Atlantic Rainforest in Brazil. Biota Neotropica 18(1): e20170445. http://dx.doi.org/10.1590/1676-0611-BN-2017-0445

\begin{abstract}
In the frame of an ongoing lichen inventory of Atlantic Rainforest remnants in Northeast Brazil, five new species of Graphidaceae were discovered in a small forest fragment, Mata do Cipó, in Sergipe state, the smallest state of Brazil and among those with the highest deforestation rate in the country. An additional new species had already been collected in Panama before and was now also found in the Mata do Cipó and is described here as well. In total, 40 species of Graphidaceae are reported for this remnant, including a large number of taxa indicative of well-preserved rainforest. The new species are: Fissurina atlantica T.A. Pereira, M. Cáceres \& Lücking, sp. nov., Graphis subaltamirensis Passos, M. Cáceres \& Lücking, sp. nov., Ocellularia cipoensis L.A. Santos, M. Cáceres \& Lücking, sp. nov., O. sosma T.A. Pereira, M. Cáceres \& Lücking, sp. nov., O. submordenii Lücking, sp. nov. (also known from Panama), and Pseudochapsa aptrootiana M. Cáceres, T.A. Pereira \& Lücking, sp. nov. The findings are discussed in the context of the strong fragmentation of the Atlantic Rainforest, with individual remnants apparently serving as refugia for residual populations of rare species of lichen fungi that were more widely distributed in the past, but currently seem to occur only in isolated fragments.
\end{abstract}

Keywords: deforestation, fragmentation, lichen diversity, Graphidaceae, refugia, Sergipe

\section{Indo extinto antes de ser descoberto? Novos fungos liquenizados da evanescente Mata Atlântica no Brasil}

\begin{abstract}
Resumo: No âmbito de um inventário atual de liquens dos remanescentes da Mata Atlântica, no Nordeste do Brasil, cinco espécies novas de Graphidaceae foram descobertas em um pequeno fragmento florestal, Mata do Cipó, no estado de Sergipe, o menor estado do Brasil, o qual está entre aqueles com maior taxa de desmatamento no país. Uma nova espécie adicional já havia sido coletada no Panamá, anteriormente, e agora também foi encontrada na Mata do Cipó, e está sendo descrita aqui também. No total, 40 espécies de Graphidaceae são relatadas para este remanescente, incluindo um grande número de táxons indicadores de floresta bem preservada. As novas espécies são: Fissurina atlantica T.A. Pereira, M. Cáceres \& Lücking, sp. nov., Graphis subaltamirensis Passos, M. Cáceres \& Lücking, sp.nov., Ocellularia cipoensis L.A. Santos, M. Cáceres \& Lücking, sp. nov., O. sosma T.A. Pereira, M. Cáceres \& Lücking, sp. nov., O. submordenii Lücking, sp. nov. (também conhecido do Panamá), e Pseudochapsa aptrootiana M. Cáceres, T.A. Pereira \& Lücking, sp. nov. Os achados são discutidos no contexto da forte fragmentação da Mata Atlântica, com remanescentes aparentemente servindo de refúgio para populações residuais de espécies raras de fungos liquenizados que, provavelmente, tiveram uma distribuição mais amplia no passado, mas que atualmente parecem ocorrer apenas em fragmentos isolados.
\end{abstract}

Palavras-chave: Desmatamento, fragmentação, diversidade de liquens, Graphidaceae, refúgios, Sergipe

\section{Introduction}

In the past centuries, extensive and continuing land use change has led to the so-called 'sixth mass extinction' or 'holocene extinction' (Leakey \& Lewin 1992; Wake \& Vredenburg 2008; Barnosky et al. 2011). Largely perceived through documented extinctions of charismatic megafauna, this phenomenon extends to many other organisms including bryophytes, lichens, and fungi. Small organisms in particular are likely to contain large numbers of undescribed species in danger of extinction before being discovered (Dirzo \& Raven 2003).

The Atlantic Rainforest is one of the most diverse ecosystems on Earth, with a high level of endemism (Mittermeier et al. 1998). Mostly 
restricted to Brazil but extending into Argentina and Uruguay, and within Brazil found in 17 states, the Atlantic Rainforest originally covered approximately $13 \%$ of the Brazilian territory, while its current extension has been reduced to about $1 \%$, with a high level of degradation and fragmentation of the remaining forest (Brooks \& Balmford 1996; Ranta et al. 1998; Ribeiro et al. 2009; Fundação SOS Mata Atlântica \& INPE 2009, 2016; Tabarelli et al. 2010). In the state of Sergipe, the smallest state in Brazil, nearly half of the territory belongs to the domain of the Atlantic Rainforest, but only about $11 \%$ of its original cover remains as more or less natural areas, dispersed into small fragments in numerous municipalities (Fundação SOS Mata Atlântica \& INPE, 2016). One of these fragments is the Mata do Cipó, a 64 ha large piece of comparatively intact forest found in the municipalities of Capela and Siriri (Fig. 1). These are among the ten municipalities with the highest deforestation rate in the state in the past two decades, out of 75 municipalities in total; together, both have about 5,000 ha forest cover left, corresponding to about $10 \%$ of their area (Fundação SOS Mata Atlântica \& INPE 2015).

The family Graphidaceae is the largest family of tropical lichens (Staiger 2002; Rivas Plata et al. 2012, 2013; Lücking et al. 2014). Its representatives occur mainly in forests in the tropical and subtropical regions of the world, mostly corticolous on tree trunks and branches (Rivas Plata et al. 2008; Lücking et al. 2014). There are currently some 2,100 species of Graphidaceae in the world, but up to 3,500 are predicted to exist (Lücking et al. 2014). The use of molecular methods has led to many taxonomic and systematic changes in the family, which now also includes Thelotremataceae, previously treated as family of its own (Staiger et al. 2006; Mangold et al. 2008; Rivas Plata et al. 2012, 2013). On the other hand, Gomphillaceae, for a while included in Graphidaceae (Rivas Plata et al. 2012), has now been shown to be its sister family (Lücking \& Lumbsch, in prep.).

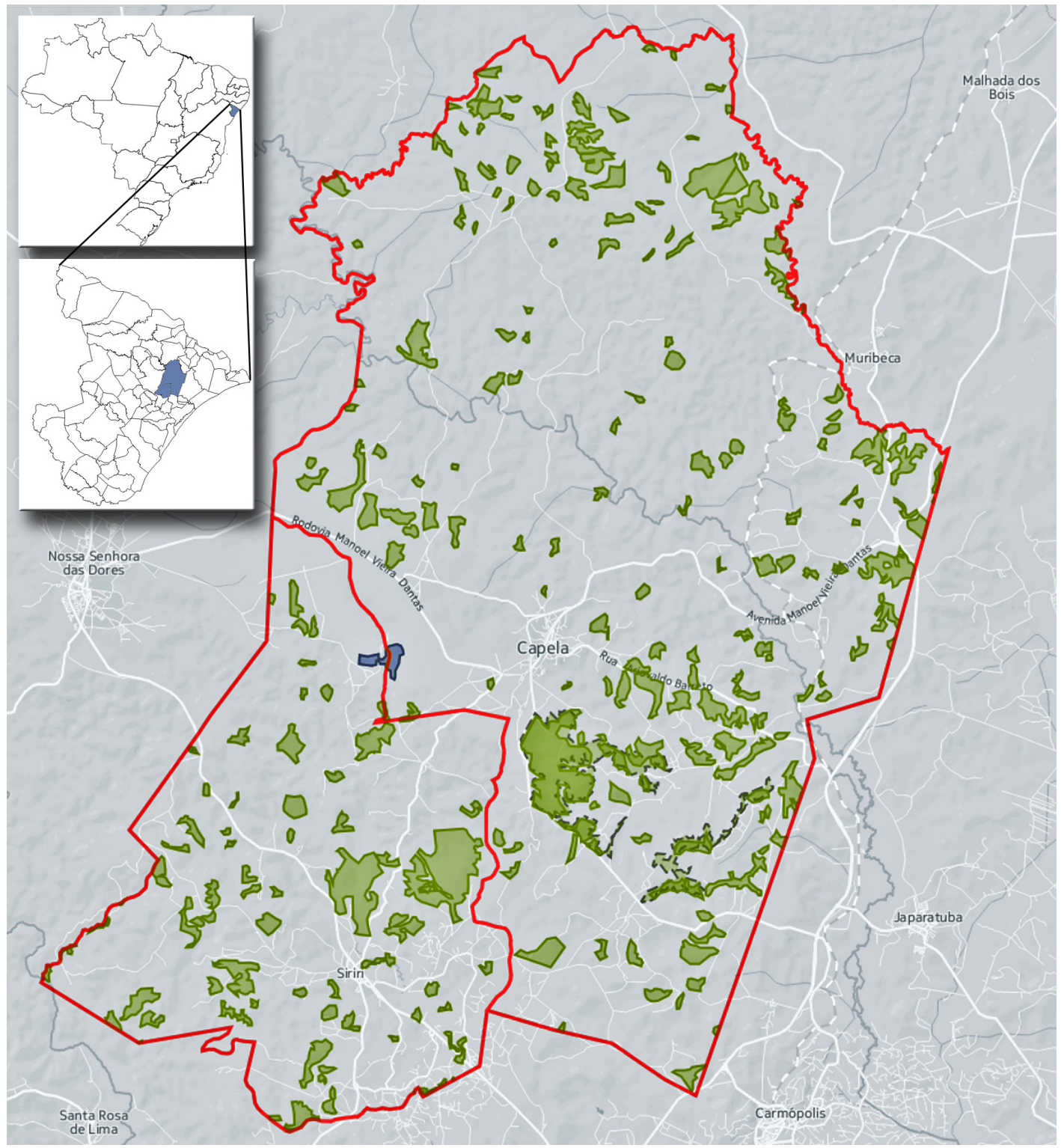

Figure 1. Location of the study site in Sergipe state, Brazil. Atlantic rain forest fragments for the two municipalities of Capela and Siriri are indicated as green areas and the study site is indicated in blue. Detailed map based on the "Aqui tem Mata?" online application [http://aquitemmata.org.br (accessed 17-11-2017)], with data from the "Atlas da Mata Atlântica", the Fundação SOS Mata Atlântica and the Instituto Nacional de Pesquisas Especiais (INPE). 
In recent years, the number of species in the Graphidaceae family has rapidly increased worldwide (Lücking et al. 2014). Many new species were recently described from Brazil, including the south (Dal Forno \& Eliasaro 2010; Käffer et al. 2010, 2014), north (Cáceres et al. 2014a), and northeast, including Sergipe state (Menezes et al. 2011; Cáceres \& Lücking 2013; Cáceres et al. 2014b). Many Graphidaceae, especially in the tribes Ocellularieae and Thelotremateae, are excellent bioindicators of intact rain forest (Rivas Plata et al. 2008), and hence specific assessments of this family can help to evaluate the conservation status of Atlantic Rainforest fragments.

The present work aimed at an inventory of Graphidaceae in the small Atlantic Rainforest fragment of the Mata de Cipó in the municipalities of Capela and Siriri in the state of Sergipe, northeast Brazil. The objective was to assess the value of such small fragments for the conservation of unique lichen species richness.

\section{Materials and Methods}

Sampling took place at the ARIE (Area of Relevant Ecological Interest) Mata do Cipó, which is located across the municipalities of Siriri and Capela, $10^{\circ} 61^{\prime} 41^{\prime \prime} \mathrm{S}$ and $37^{\circ} 11^{\prime} 87^{\prime \prime}$, in Sergipe state (Fig. 1). The Mata do Cipó comprises approximately 64 ha of Atlantic Rainforest, situated at 80-100 m altitude, characterized as a semideciduous seasonal rainforest, with some parts in regeneration (Umbelino 2012). Lichens were collected using an opportunistic sampling method along the trails through forest (Gradstein et al. 1996; Cáceres et al. 2008).

Identification of the material was done using a LEICAEZ4 stereomicroscope and a LEICA DM500 compound microscope at the Laboratório de Liquenologia (LALIQ), Departamento de Biociências da Universidade Federal de Sergipe, Campus Professor Alberto Carvalho, in Itabaiana, Sergipe. Voucher specimens were deposited in the herbarium of the Laboratório de Liquenologia (ISE). The following taxonomic works were consulted to identify the genera and species: Staiger (2002; graphidoid Graphidaceae), Kalb et al. (2004; Diorygma), Frisch et al. (2006; thelotremoid Graphidaceae), Lücking et al. (2009, 2016; Graphis, Myriotrema), Rivas Plata et al. (2010; thelotremoid Graphidaceae), Gaswick \& Lücking (2012; thelotremoid Graphidaceae), Lücking (2014; Ocellularia), and Feuerstein et al. (2014; Diorygma). All identifications were verified by comparison with data from authentic type material, in part consulting types digitized through the Global Plants Initiative [http://gpi.myspecies.info; https://plants.jstor.org]. Thin-layer chromatography was performed using standard methods as described in Orange et al. (2010).

\section{Results and Discussion}

Of the lichen fungi thus far identified in material collected in the Mata do Cipó, 40 species belong to the family Graphidaceae, distributed in 15 genera (Table 1). Six new species are described below, five of these based on material from the study site and one previously collected in Panama (Fig. 2-4). Four species are newly reported for Brazil and further six are new records for Sergipe state (Fig. 5-6).

At first glance, a number of 40 Graphidaceae appears to be fairly low for an area of tropical rain forest. For instance, 131 species were reported from the Surumoni crane station in Venezuela (Komposch \& Hafellner 1999), 116 from Los Amigos Biological Station in Amazonian Peru (Rivas Plata \& Lücking 2013), and 111 from Fakahatchee Strand Park Preserve in Florida (Lücking et al. 2011). However, these numbers are not directly comparable, as the latter areas are by several orders of magnitude larger and embedded into vast regions of intact tropical rain forests; for instance, Los Amigos covers 145,000 ha and Fakahatchee 25,000 ha, compared to the 64 ha of Mata do Cipó. Of the 116 species from Los Amigos, 18 (15.5\%) were new to science, 13 of which (11.2\%) represented thelotremoid genera; at Fakahatchee, 13 out of the 111 species $(11.7 \%)$ were new, with no thelotremoid taxon. Of the 40 species found at Mata do Cipó, $15 \%$ were new to science, $10 \%$ representing thelotremoid genera, thus with proportions comparable to the much larger and better preserved areas. Most notably, 23 Atlantic rain forest fragments have now been studied in six states in northeastern Brazil by our working group (Cáceres et al. 2017), and yet this very small fragment revealed so far the largest number of new Graphidaceae. The total number of 20 thelotremoid species, representing eight different morphotypes in the classification provided by Rivas Plata et al. (2008), suggests the Mata do Cipó to be a rather well preserved, near-intact piece of Atlantic Rainforest worth further protecting. Five years ago, it was actually proposed to transform this fragment into a legally protected area (SEMARH 2012); however, we are unaware of the status of this process.

The discovery of six new species in a small area of Atlantic rain forest at first glance might suggests a very local distribution of these species, that is, a high degree of local endemism. However, given that the Atlantic Rainforest originally formed a broader, continuous strip along the coast in this part of Brazil, we hypothesize that the current distribution patterns are a relict of originally broader distributions. Most of these lichen fungi are very rare and hence, a high degree of fragmentation will stochastically eliminate many regional and local populations, with few or single populations remaining in particular fragments in more or less random patterns. As a consequence, each fragment harbors a unique component of the overall remaining diversity of the Atlantic Rainforest. One could consider these refugia, similar to Pleistocene refugia (Grazziotin et al. 2006), although the nature of the environmental changes is quite different, and these changes occur much faster, not allowing for evolutionary adaptations.

Since lichen communities adapted to intact forest, in particular thelotremoid Graphidaceae (Rivas Plata et al. 2008), are unable to adjust to fast environmental changes, forest fragmentation basically results in depauperation, with randomly dispersed relict populations. As a consequence, fragment size is not necessarily a predictor for species richness or occurrence of unique taxa. For instance, the Refugio de Vida Silvestre Mata do Junco, the second largest fragment of Atlantic Rainforest in Sergipe state with 894 ha (SEMARH 2013), yielded thus far 28 species of Graphidaceae, one of them new to science (Cáceres et al. 2017). The overlap in species composition of Graphidaceae between both fragments is extremely low, with just one species (Graphis glaucescens) in common. This appears to be contrast to findings for vascular plants and animals, in which community formation usually responds to disturbances through community changes, correlated both with fragment size and degree of isolation, with ruderal species becoming increasingly dominant in smaller, more isolated fragments (Tabarelli et al. 1999; Uezu et al. 2005; Galetti et al. 2006). However, one should not underestimate sampling artifacts concerning small organisms such as lichens, since only the more common species will be regularly collected, so even thorough sampling may not detect all taxa and hence differences in composition might be in part due to this effect. Also, the material collected at Mata do Junco has not been fully evaluated and might contain more species of Graphidaceae.

\section{Taxonomic treatment of the new species}

Fissurina atlantica T.A. Pereira, M. Cáceres \& Lücking, sp. nov. (Fig. 2A) MycoBank MB 823652

Diagnosis: Differing from other species of Fissurina in the sorediate thallus forming maculate soralia.

Holotype: Brazil. Sergipe: Capela e Siriri, ARIE Mata do Cipó; $10^{\circ} 61^{\prime} 41^{\prime \prime} \mathrm{S}, 37^{\circ} 11$ '87', 80-100 m; Atlantic Rainforest remnant, corticolous in understory; 18 September 2015, T.A. Pereira \& P.O. Passos (ISE 36371).

Etymology: Referring to the Atlantic Rainforest.

Description: Thallus corticolous, epiperidermal, $1-5 \mathrm{~cm}$ diam., continuous; surface uneven-verrucose, white-grey to pale yellowish grey or cream-colored; 
Pereira, T.A. et al.

Table 1: List of Graphidaceae found in the ARIE Mata do Cipó, Sergipe state, Brazil. New species found so far only at this locality are highlighted in boldface; a further new species (O. submordenii) was first discovered in Panama.

\begin{tabular}{|c|c|c|}
\hline Species & Morphotype & Novelty \\
\hline Carbacanthographis subalbotecta Staiger \& Kalb & graphidoid & new for Sergipe \\
\hline Diorygma junghuhnii (Mont. \& Bosch) Kalb, Staiger \& Elix & graphidoid & \\
\hline Diorygma minisporum Kalb, Staiger \& Elix & graphidoid & new for Sergipe \\
\hline Diorygma poitaei (Fée) Kalb, Staiger \& Elix & graphidoid & \\
\hline Fissurina amazonica M. Cáceres, Aptroot \& Lücking & graphidoid & new for Sergipe \\
\hline Fissurina atlantica T. A. Pereira, M. Cáceres \& Lücking & graphidoid & new species \\
\hline Fissurina bothynocarpa (Redinger) Lücking & graphidoid & \\
\hline Graphis conferta Zenker & graphidoid & \\
\hline Graphis glaucescens Fée & graphidoid & \\
\hline Graphis miniata Redinger & graphidoid & new for Sergipe \\
\hline Graphis oxyclada Müll. Arg. & graphidoid & \\
\hline Graphis subaltamirensis Passos, M. Cáceres \& Lücking & graphidoid & new species \\
\hline Graphis subtenella Müll. Arg. & graphidoid & new for Brazil \\
\hline Phaeographis brasiliensis (A. Massal.) Kalb \& Matthes-Leicht & graphidoid & \\
\hline Phaeographis flavescens Dal-Forno \& Eliasaro & graphidoid & new for Sergipe \\
\hline Phaeographis haematites (Fée) Müll. Arg. & graphidoid & \\
\hline Phaeographis scalpturata (Ach.) Staiger & graphidoid & \\
\hline Platythecium grammitis (Fée) Staiger & graphidoid & \\
\hline Sarcographa labyrinthica (Ach.) Müll. Arg. & graphidoid & \\
\hline Thalloloma hypoleptum (Nyl.) Staiger & graphidoid & new for Sergipe \\
\hline Chapsa diploschistoides (Zahlbr.) Frisch & thelotremoid & new for Brazil \\
\hline Chapsa elabens (Müll. Arg.) Rivas Plata \& Mangold & thelotremoid & \\
\hline Chapsa thallotrema Lücking \& N. Salazar & thelotremoid & \\
\hline Glaucotrema costaricense (Müll. Arg.) Rivas Plata \& Lumbsch & thelotremoid & \\
\hline Leucodecton fissurinum (Hale) Frisch & thelotremoid & \\
\hline Leucodecton subcompunctum (Nyl.) Frisch & thelotremoid & \\
\hline Melanotrema platystomum (Mont.) Frisch & thelotremoid & \\
\hline Myriotrema microporum (Mont.) Hale & thelotremoid & \\
\hline Ocellularia cavata (Ach.) Müll. Arg. & thelotremoid & \\
\hline Ocellularia aff. cavata (Ach.) Müll. Arg. & thelotremoid & \\
\hline Ocellularia cipoensis L.A. Santos, M. Cáceres \& Lücking & thelotremoid & new species \\
\hline Ocellularia crocea (Kremp.) Overeem \& D. Overeem & thelotremoid & \\
\hline Ocellularia dolichotata (Nyl.) Zahlbr. & thelotremoid & \\
\hline Ocellularia aff. mordenii Hale & thelotremoid & \\
\hline Ocellularia obturascens (Nyl.) Hale & thelotremoid & \\
\hline Ocellularia sosma T. A. Pereira, M. Cáceres \& Lücking & thelotremoid & new species \\
\hline Ocellularia submordenii Lücking & thelotremoid & new species \\
\hline Ocellularia violacea Räsänen & thelotremoid & new for Brazil \\
\hline Ocellularia zamorana Sipman, Lücking \& Chaves & thelotremoid & new for Brazil \\
\hline Pseudochapsa aptrootiana M. Cáceres, T. A. Pereira \& Lücking & thelotremoid & new species \\
\hline
\end{tabular}

prothallus absent; soralia present and abundant, well-delimited, rounded to slightly irregular in outline, erumpent, crateriform to excavate, $0.3-0.6 \mathrm{~mm}$ diam.; soredia mealy-granular, white. Thallus in section 30-50 $\mu \mathrm{m}$ thick, with loose upper cortex, 5-10 $\mu \mathrm{m}$ thick, and irregular photobiont layer 25-40 $\mu \mathrm{m}$ thick. Photobiont Trentepohlia; cells rounded to irregular in outline, in irregular groups, yellowish green, $8-10 \times 6-9 \mu \mathrm{m}$. Ascomata lirelliform, flexuose, more or less stellately branched, erumpent, with thin but distinct, gaping labia and complete thalline margin, $0.5-1.5 \mathrm{~mm}$ long, $0.1-0.2 \mathrm{~mm}$ wide, $0.07-0.1 \mathrm{~mm}$ high; disc partially exposed, flesh-colored, thinly white-pruinose; proper margin indistinct, labia entire; thalline margin whitish. Excipulum 50-10 $\mu \mathrm{m}$ wide, pale yellowish; laterally covered by algiferous thallus including clusters of crystals in basal parts; hypothecium prosoplectenchymatous, 5-10 $\mathrm{mm}$ high, colorless; hymenium
50-60 $\mu \mathrm{m}$ high, colorless, clear; epithecium granulose, 5-10 $\mu \mathrm{m}$ high, grey. Asci fusiform, $50-60 \times 6-8 \mu \mathrm{m}$. Ascospores 8 per ascus, oblong-ellipsoid, 3(-4)-septate, 10-12 × 3-4 $\mu \mathrm{m}, 3-3.5$ times as long as wide, colorless. Secondary chemistry: No substances detected by TLC.

Remarks: This new species is the first within the genus Fissurina to form soralia. Without the ascomata, the sterile thallus would probably have been classified tentatively within a different genus, such as Chapsa or Ocellularia, which include several sorediate species. However, this find shows that the formation of soralia is more widespread within the family, although generally still rare. The verrucose thallus is also unusual for a species of this genus.

Graphis subaltamirensis Passos, M. Cáceres \& Lücking, sp. nov. (Fig. 2B) MycoBank MB 823653 

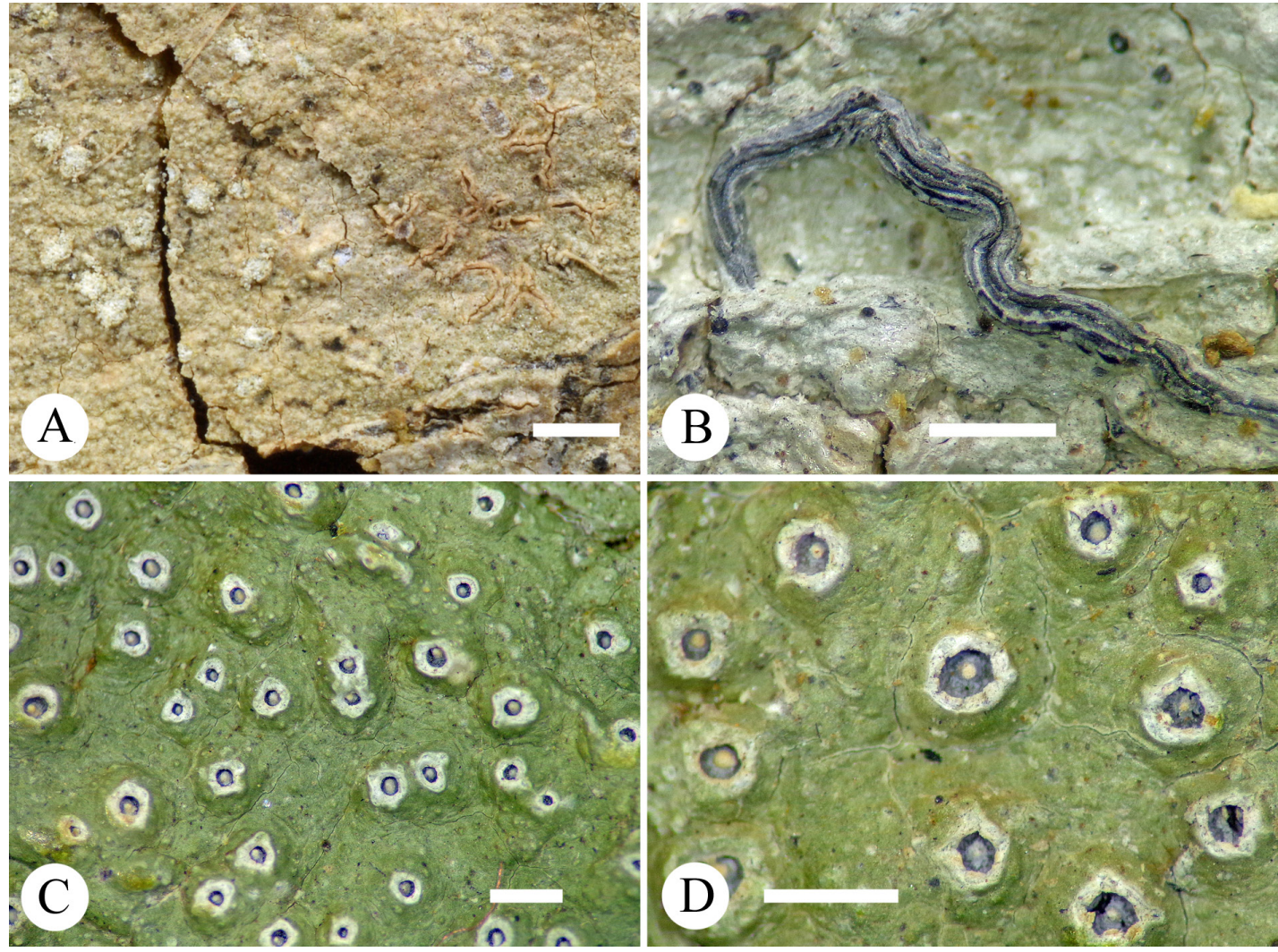

Figure 2. Habit of new species. A. Fissurina atlantica (holotype), thallus with soralia and clusters of lirellae. B. Graphis subaltamirensis (holotype), thallus with lirella. C-D. Ocellularia cipoensis (C, holotype; D, ISE 36119), thallus with ascomata. Scale bar $=1 \mathrm{~mm}$.
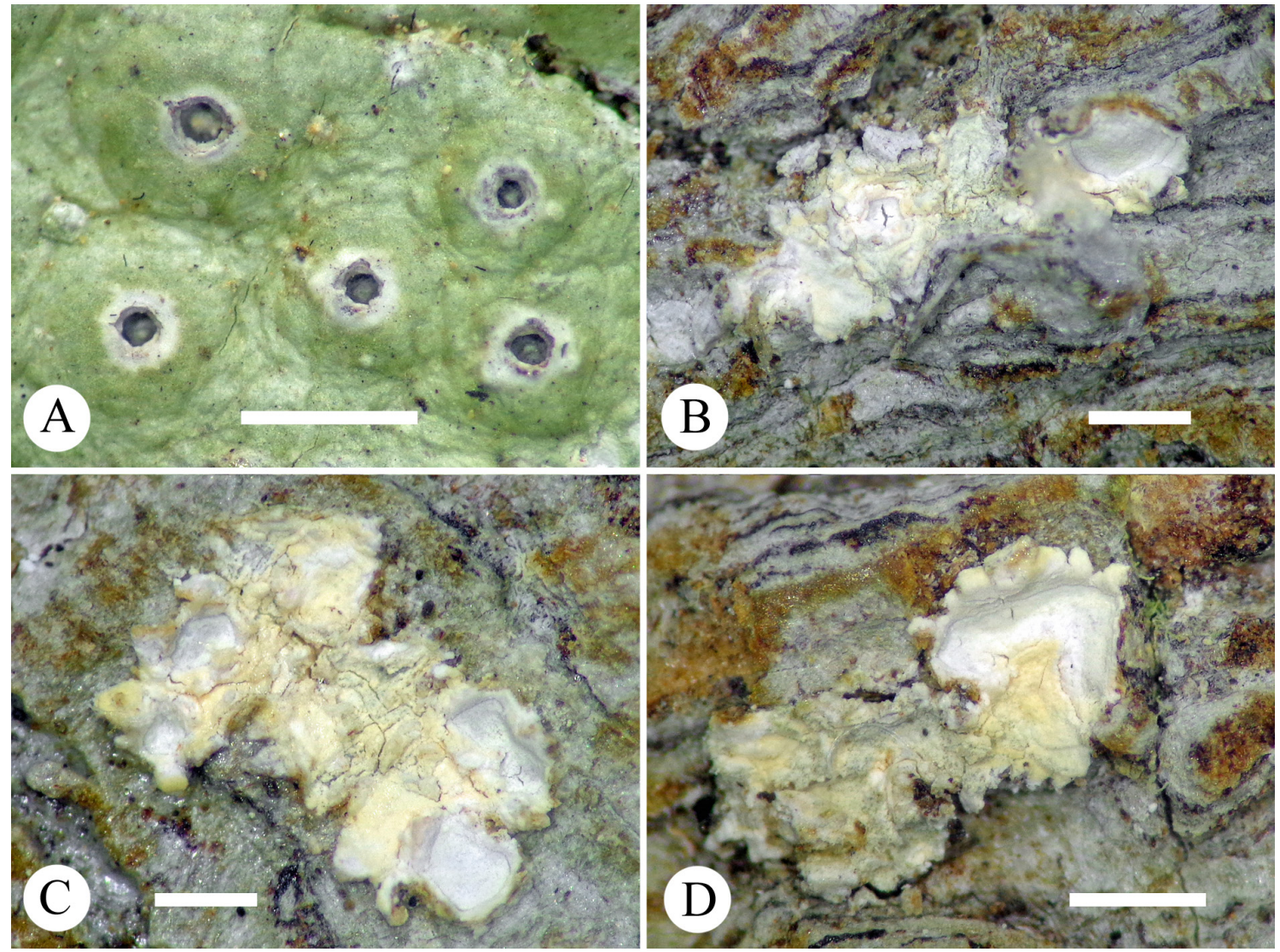

Figure 3. Habit of new species. A. Ocellularia sosma (ISE 36537), thallus with ascomata. B-D. Pseudochapsa aptrootiana (holotype), thallus with ascomata. Scale bar=1 mm. 

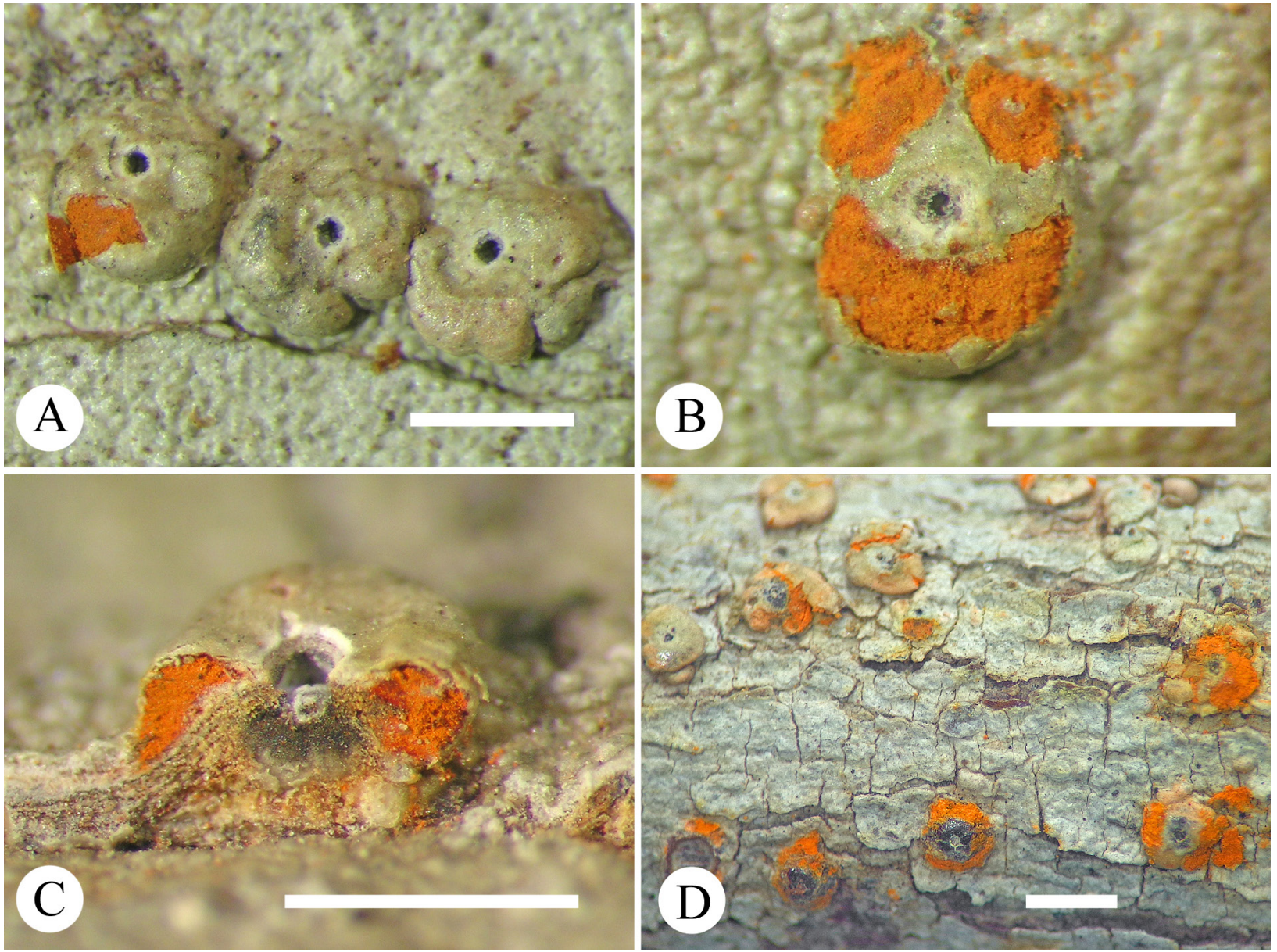

Figure 4. Habit of new species. A-D. Ocellularia submordenii (A-C, holotype from Panama; D, ISE 36125), thallus with ascomata, in B showing exposed medulla, in $\mathrm{C}$ showing section. Scale bar $=1 \mathrm{~mm}$.

Diagnosis: Differing from Graphis altamirensis in the shorter ascospores.

Holotype: Brazil. Sergipe: Capela e Siriri, ARIE Mata do Cipó; $10^{\circ} 61^{\prime} 41^{\prime \prime} \mathrm{S}, 37^{\circ} 11^{\prime} 87^{\prime \prime}, 80-100 \mathrm{~m}$; Atlantic Rainforest remnant, corticolous in understory; 18 September 2015, T.A. Pereira \& P.O. Passos (ISE 36083).

Etymology: Referring to the similarity with Graphis altamirensis.

Description: Thallus corticolous, epiperidermal, $1-5 \mathrm{~cm}$ diam., continuous; surface uneven, white-grey; prothallus absent. Thallus in section 100-150 $\mu \mathrm{m}$ thick, with cartilaginous upper cortex, 5-10 $\mu \mathrm{m}$ thick, and irregular photobiont layer 50-100 $\mu \mathrm{m}$ thick, with large clusters of calcium oxalate crystals. Photobiont Trentepohlia; cells rounded to irregular in outline, in irregular groups, yellowish green, 8-12 × 6-9 $\mu \mathrm{m}$. Ascomata lirelliform, flexuose, unbranched to sparsely branched, prominent to almost sessile, with thick labia and apically thin complete thalline margin, $3-8 \mathrm{~mm}$ long, 0.4-0.5 mm wide, 0.3-0.5 $\mathrm{mm}$ high; disc concealed; proper margin very thick, labia striate, dark gray to gray-black with white lines; thalline margin laterally thick, gray to white, apically thin (cortex only), gray. Excipulum apically crenulate, completely carbonized, 130-170 $\mu \mathrm{m}$ wide, black; laterally covered by corticate algiferous thallus including clusters of crystals in basal parts; hypothecium prosoplectenchymatous, 15-25 mm high, colorless; hymenium 130-170 $\mu \mathrm{m}$ high, colorless, strongly inspersed (paraphyses and asci hardly visible), inspersion rapidly disappearing in $\mathrm{KOH}$ (type $\mathrm{B}$ ); epithecium granulose, 5-15 $\mu \mathrm{m}$ high, olive brown. Asci fusiform, 120-150 × 25-30 $\mu \mathrm{m}$. Ascospores (4-)8 per ascus, oblong, submuriform with 15-19 transverse and 0-1 longitudinal septa per segment, $70-100 \times(10-) 12-17 \mu \mathrm{m}, 5-6$ times as long as wide, colorless. Secondary chemistry: No substances detected by TLC.

Remarks: This species is most similar to Graphis altamirensis, G. cinerea, and $G$. pseudocinerea, agreeing in the robust, prominent (to sessile), striate lirellae with fully and massively carbonized excipulum and strongly inspersed hymenium, lacking secondary substances. Graphis altamirensis differs in the much longer ascospores $(120-180 \times 10-15 \mu \mathrm{m}, 10-14$ times as long as wide), whereas G. pseudocinerea has smaller (50-70 ×9-12 $\mu \mathrm{m})$, regularly muriform ascospores with numerous longitudinal septa. Graphis cinerea lacks longitudinal septa in the much larger and broader ascospores $(100-200 \times 18-30 \mu \mathrm{m})$.

Additional specimens examined: Brazil. Sergipe: Capela e Siriri, ARIE Mata do Cipó; 1061'41" S, 37 ¹1'87”, 80-100 m; Atlantic Rainforest remnant, corticolous in understory; 18 September 2015, T.A. Pereira \& P.O. Passos (ISE 36035, 36058, 36063).

Ocellularia cipoensis L.A. Santos, M. Cáceres \& Lücking, sp. nov. (Fig. 2C-D)

MycoBank MB 823654

Diagnosis: Differing from Ocellularia rondoniana in the verrucose instead of ridged thallus, the slightly larger pore of the ascomata, and the slightly larger ascospores.

Holotype: Brazil. Sergipe: Capela e Siriri, ARIE Mata do Cipó; 1061'41”S, $37^{\circ} 11$ '87', 80-100 m; Atlantic Rainforest remnant, corticolous in understory; 18 September 2015, T.A. Pereira \& P.O. Passos (ISE 36116). 

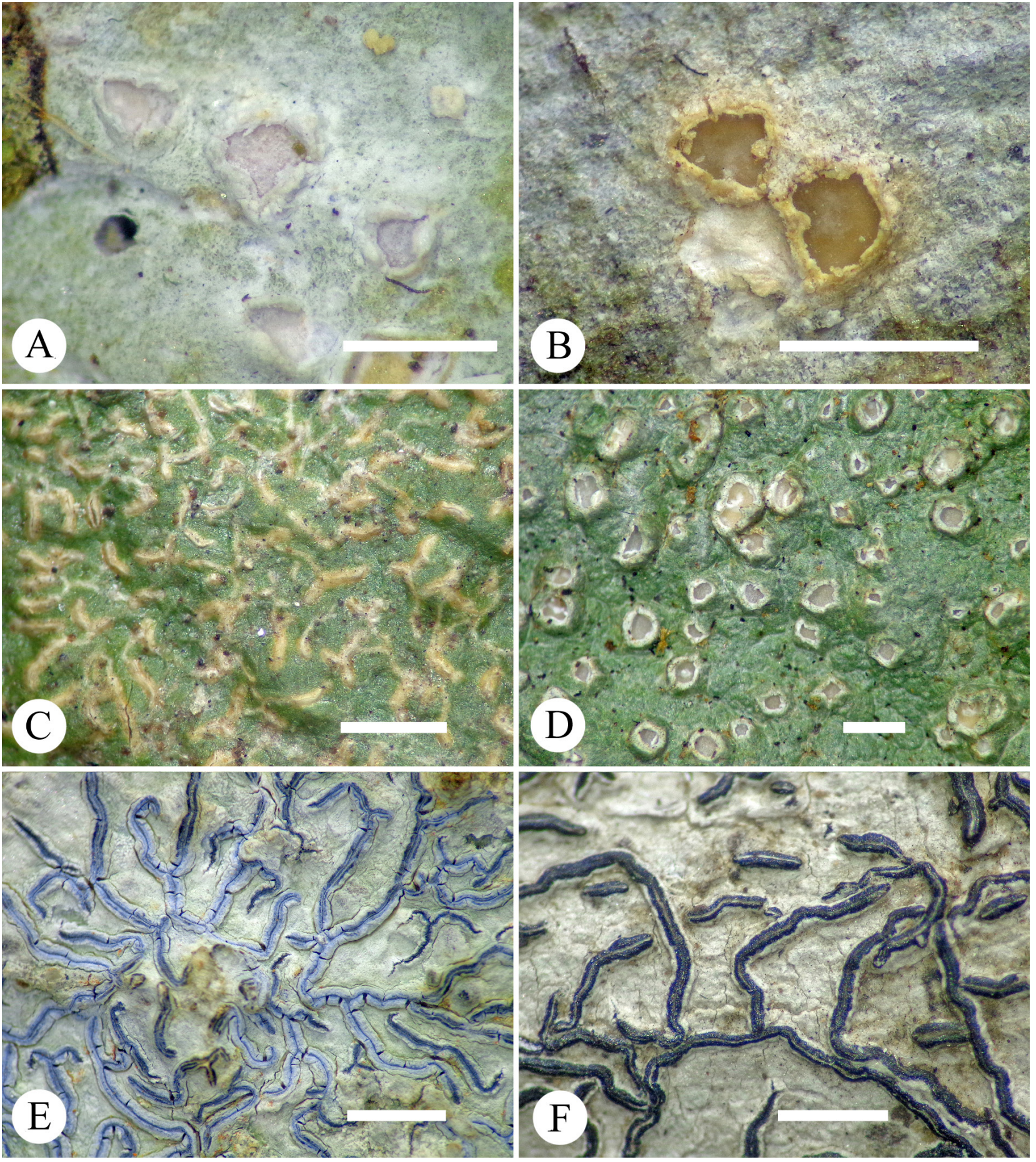

Figure 5. Habit of new or otherwise interesting records of Graphidaceae from Mata do Cipó. A. Chapsa diploschistoides (ISE 36046), thallus with ascomata. B. C. elabens (ISE 36049), thallus with ascomata. C. Fissurina amazonica (ISE 36521), thallus with lirellae. D. Glaucotrema costaricense (ISE 36117), thallus with ascomata. E. Graphis glaucescens (ISE 36104), thallus with lirellae. F. G. oxyclada (ISE 36063), thallus with lirellae. Scale bar $=1 \mathrm{~mm}$.

Etymology: Referring to the type locality, the Mata do Cipó.

Description: Thallus corticolous, epiperidermal, up to c. $5 \mathrm{~cm}$ diam., continuous; surface verrucose, light green-grey; prothallus absent. Thallus in section 100-150 $\mu \mathrm{m}$ thick, with prosoplectenchymatous cortex, $10-15 \mu \mathrm{m}$ thick, photobiont layer 30-80 $\mu \mathrm{m}$ thick, and irregular medulla, 30-50 $\mu \mathrm{m}$ thick, strongly encrusted with numerous small, grey crystals that partially dissolve in $\mathrm{K}$, and large clusters of calcium oxalate crystals forming the verrucae. Photobiont Trentepohlia; cells rounded to irregular in outline, in irregular groups, yellowish green, $8-11 \times 7-9 \mu \mathrm{m}$. Ascomata rounded to angular, erumpent, with complete thalline margin, $0.7-1.1 \mathrm{~mm}$ diam., $0.2-0.3 \mathrm{~mm}$ high; disc covered by $0.2-0.4 \mathrm{~mm}$ wide pore; proper margin distinct, entire, visible as $0.1-0.2$ 

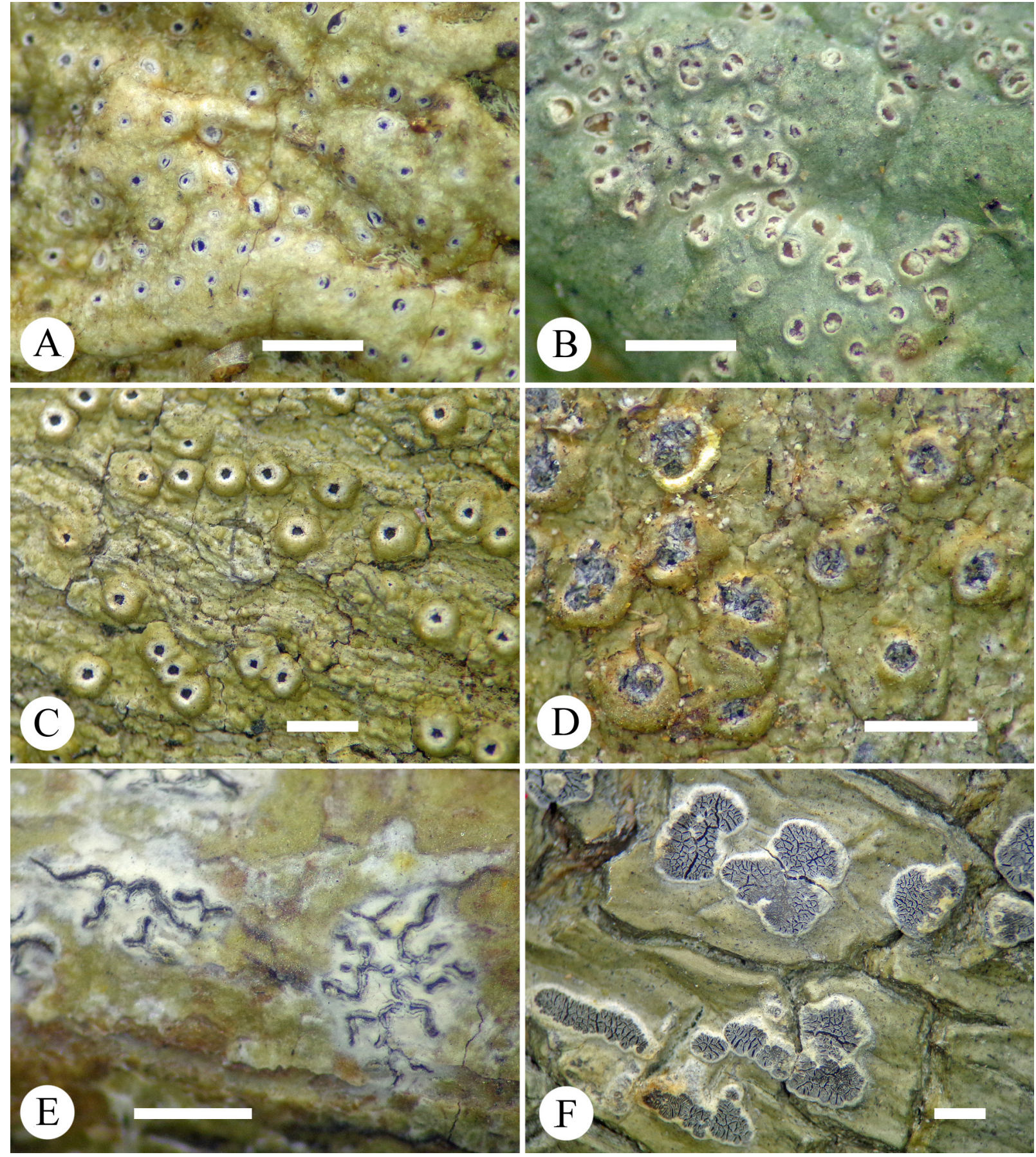

Figure 6. Habit of new or otherwise interesting records of Graphidaceae from Mata do Cipó. A. Leucodecton subcompunctum (ISE 36069), thallus with ascomata B. Myriotrema microporum (ISE 36534), thallus with ascomata. C. Ocellularia cavata (ISE 36067), thallus with ascomata. D. O. crocea (ISE 36124), thallus with ascomata. E. Phaeographis brasiliensis (ISE 36057a), thallus with lirellae. F. Sarcographa labyrinthica (ISE 36211), thallus with lirellae. Scale bar $=1 \mathrm{~mm}$.

$\mathrm{mm}$ broad, white, angular rim around the pore; thalline margin entire, verrucose, light green-grey. Excipulum entire, light yellow-brown to orange-brown (difficult to separate from modified periderm), together with periderm $70-150 \mu \mathrm{m}$ wide, fused with thalline margin; laterally covered by algiferous, corticate thallus containing periderm layers; columella present, finger-like, $100-150 \mu \mathrm{m}$ broad, thinly carbonized; hypothecium prosoplectenchymatous, $10-15 \mu \mathrm{m}$ high, hyaline; hymenium
100-120 $\mu \mathrm{m}$ high, hyaline, clear; epithecium indistinct, $10-15 \mu \mathrm{m}$ high, hyaline. Paraphyses unbranched, apically smooth; periphysoids absent; asci cylindrical, $95-110 \times 8-10 \mu \mathrm{m}$. Ascospores 8 per ascus, ellipsoid, 5-7-septate, 20-30 $\times 6-8 \mu \mathrm{m}, 3-4$ times as long as wide, hyaline, distoseptate with lens-shaped lumina, I+ violet-blue. Secondary chemistry: Psoromic (major), subpsoromic (minor), and 2'-O-demethylpsoromic acids (minor to trace); medulla $\mathrm{P}+$ yellow, microscopic section $\mathrm{K}-$. 
Remarks: This new species agrees with the recently described Ocellularia rondoniana from the Brazilian Amazon in most features, including ascoma morphology and anatomy, but differs in the verrucose instead of ridged thallus, the larger pore of the ascomata $(0.15-0.25 \mathrm{~mm}$ in $O$. rondoniana $)$ and the slightly larger ascospores $(17-23 \times 5-7 \mu \mathrm{m}$ in $O$. rondoniana). Both species are known from several well-developed collections and the differences are consistent.

Additional specimens examined: Brazil. Sergipe: Capela e Siriri, ARIE Mata do Cipó; $10^{\circ} 61^{\prime} 41^{\prime \prime}$ S, $37^{\circ} 11$ '87', 80-100 m; Atlantic Rainforest remnant, corticolous in understory; 18 September 2015, T.A. Pereira \& P.O. Passos (ISE 36119); ibid., 17 March 2016, T.A. Pereira \& P.O. Passos (ISE 36114).

Ocellularia sosma T. A. Pereira, M. Cáceres \& Lücking, sp. nov. (Fig. 3A)

MycoBank MB 823655

Diagnosis: Differing from Ocellularia rondoniana in the thallus lacking ridges and the columella forming thin, irregular strands.

Holotype: Brazil. Sergipe: Capela e Siriri, ARIE Mata do Cipó; $10^{\circ} 61^{\prime} 41^{\prime \prime} \mathrm{S}, 37^{\circ} 11^{\prime} 87^{\prime}$, 80-100 m; Atlantic Rainforest remnant, corticolous in understory; 17 March 2016, T.A. Pereira \& P.O. Passos (ISE 36519).

Etymology: The epithet honors the work of the foundation SOS Mata Atlântica (SOSMA) in conserving the Atlantic Rainforest.

Description: Thallus corticolous, epiperidermal, up to c. $7 \mathrm{~cm}$ diam., continuous; surface uneven to shallowly verrucose, light grey-green; prothallus absent. Thallus in section 50-100 $\mu \mathrm{m}$ thick, with prosoplectenchymatous cortex, 10-20 $\mu \mathrm{m}$ thick, photobiont layer $40-80 \mu \mathrm{m}$ thick, and indistinct medulla, photobiont layer encrusted with numerous small, gray crystals that partially dissolve in $\mathrm{K}$, and scattered, large clusters of calcium oxalate crystals forming the verrucae. Photobiont Trentepohlia; cells rounded to irregular in outline, in irregular groups, yellowish green, $8-12 \times 7-10 \mu \mathrm{m}$. Ascomata rounded, erumpent, with complete thalline margin, $0.7-1.2 \mathrm{~mm}$ diam., $0.2-0.3 \mathrm{~mm}$ high; disc covered by $0.1-0.2(-0.3) \mathrm{mm}$ wide pore; proper margin distinct, entire, visible as white rim around the pore; thalline margin entire, smooth to uneven, light grey-green. Excipulum entire, yellow-olive, externally covered by dark brown periderm, together with periderm 70-120 $\mu \mathrm{m}$ wide, fused with thalline margin; laterally covered by algiferous thallus; columella present in part of the ascomata, absent in others, when present forming one to several, thin strands, $25-50 \mu \mathrm{m}$ broad, carbonized; hypothecium prosoplectenchymatous, 10-15 $\mu \mathrm{m}$ high, hyaline; hymenium 90-100 $\mu \mathrm{m}$ high, hyaline, clear; epithecium distinct, 10-15 $\mu \mathrm{m}$ high, gray-granular. Paraphyses unbranched, apically smooth; periphysoids absent; asci cylindrical, 85-95 × 8-10 $\mu \mathrm{m}$. Ascospores (few mature ones seen) 8 per ascus, ellipsoid, 5-7-septate, 18-25 × 6-8 $\mu \mathrm{m}, 3-4$ times as long as wide, hyaline, distoseptate with lens-shaped lumina, I+ violet-blue. Secondary chemistry: Psoromic (major), subpsoromic (minor), and 2'-O-demethylpsoromic acids (minor to trace); medulla $\mathrm{P}+$ yellow, microscopic section $\mathrm{K}-$.

Remarks: This new species belongs in the difficult Ocellularia terebrata complex (Lücking 2014), within which it is characterized by a non-carbonized excipulum combined with a carbonized columella. The species somewhat resembles $O$. rondoniana $\mathrm{M}$. Cáceres, Aptroot \& Lücking, but differs in thallus structure and especially in the columella forming thin, irregular strands, while other species in this group have finger-like to broad-stump-shaped columellas.

Additional specimens examined: Brazil. Sergipe: Capela e Siriri, ARIE Mata do Cipó; $10^{\circ} 61^{\prime} 41^{\prime \prime} \mathrm{S}, 37^{\circ} 11^{\prime} 87^{\prime \prime}, 80-100$ m; Atlantic Rainforest remnant, corticolous in understory; 17 March 2016, T.A. Pereira \& P.O. Passos (ISE 36537).

Ocellularia submordenii Lücking, sp. nov. (Fig. 4A-D)

MycoBank MB 823656
Diagnosis: Differing from Ocellularia mordenii in the more delicately verrucose thallus and the orange instead of cinnabar-red medullary pigment, as well as the regularly columellate apothecia.

Holotype: Panama. Colón: Santa Rita Ridge, about $6 \mathrm{~km}$ from Roosevelt Highway; 350 m; logged primary forest and remnant stands; 1974, M. Hale 43501 (US).

Etymology: The epithet refers to the similarity with Ocellularia mordenii.

Description: Thallus corticolous, epiperidermal, up to c. $7 \mathrm{~cm}$ diam., continuous; surface verrucose, light greyish olive; prothallus absent. Thallus in section 100-150 $\mu \mathrm{m}$ thick, with loose, irregular, cartilaginous cortex, 10-15 $\mu \mathrm{m}$ thick, photobiont layer 50-100 $\mu \mathrm{m}$ thick, and indistinct medulla, partially encrusted orange pigment granules. Photobiont Trentepohlia; cells rounded to irregular in outline, in irregular groups, yellowish green, 9-12 $\times 8-10 \mu \mathrm{m}$. Ascomata rounded, prominent, with complete but often eroding thalline margin, $0.7-1.2 \mathrm{~mm}$ diam., $0.3-0.4 \mathrm{~mm}$ high; disc covered by $0.1-0.2 \mathrm{~mm}$ wide pore filled with white-pruinose columella; proper margin thin, entire, visible as white rim around the pore; thalline margin entire, verrucose, light greyish olive. Excipulum entire, apically carbonized, laterally covered by a thick layer of brown periderm and above with a massive layer of orange medulla, together with periderm 200-300 $\mu \mathrm{m}$ thick, fused with thalline margin; laterally covered by corticate algiferous thallus; columella present, finger-like, 50-100 $\mu \mathrm{m}$ broad, upper half carbonized; hypothecium prosoplectenchymatous, 10-20 $\mu \mathrm{m}$ high, hyaline; hymenium 150-200 $\mu \mathrm{m}$ high, hyaline, clear; epithecium distinct, 10-15 $\mu \mathrm{m}$ high, gray-granular. Paraphyses unbranched, apically smooth; periphysoids absent; asci cylindrical, $130-170 \times 30-40 \mu \mathrm{m}$. Ascospores 1-2 per ascus, oblong, 21-29-septate, $70-150 \times 15-20 \mu \mathrm{m}, 5-8$ times as long as wide, hyaline, distoseptate with lens-shaped lumina, I+ violet-blue. Secondary chemistry: unidentified orange anthraquinone, $\mathrm{K}+$ purple.

Remarks: This new species was first collected 1974 in Panama by Mason Hale and identified with Ocellularia mordenii Hale, described previously from Dominica (Hale 1974, 1978). However, the latter differs in the much more coarsely verrucose-areolate thallus and in the cinnabar-red instead of orange medullary pigment and most apothecia lack a columella. With the additional discovery of this undescribed taxon in the Atlantic Rainforest fragment studied here, the time has come to formally describe it.

The new species was reported in the supplementary material (data spreadsheet) in Cáceres et al. (2017: Appendix A: line 512) as "Ocellularia submardinis" [sic], an unfortunate typographical error.

Additional specimens examined: Brazil. Sergipe: Capela e Siriri, ARIE Mata do Cipó; 1061'41" S, $37^{\circ} 11$ '87', 80-100 m; Atlantic Rainforest remnant, corticolous in understory; 18 September 2015, T.A. Pereira \& P.O. Passos (ISE 36126).

Pseudochapsa aptrootiana M. Cáceres, T.A. Pereira \& Lücking, sp. nov. (Fig. 3D-F)

MycoBank MB 823657

Diagnosis: Differing from Pseudochapsa phlyctidioides in the endoperidermal thallus and the aggregate-pseudostromatic ascomata with thick, cream-white pruina, and the slightly larger ascospores.

Holotype: Brazil. Sergipe: Capela e Siriri, ARIE Mata do Cipó; $10^{\circ} 61^{\prime} 41^{\prime \prime} \mathrm{S}, 37^{\circ} 11$ '87', 80-100 m; Atlantic Rainforest remnant, corticolous in understory; 18 September 2015, T.A. Pereira \& P.O. Passos (ISE 36059).

Etymology: This new species is dedicated to our esteemed colleague, mentor and friend, André Aptroot, for his invaluable contributions to tropical lichenology.

Description: Thallus corticolous, endoperidermal, up to c. $3 \mathrm{~cm}$ diam., continuous; surface uneven, following the relief of the bark, light grey; prothallus absent. Thallus in section $30-50 \mu \mathrm{m}$ thick, ecorticate, with partially endoperidermal photobiont layer, 10-30 $\mu \mathrm{m}$ thick, and irregular medulla, 10-20 $\mu \mathrm{m}$ thick. Photobiont Trentepohlia; cells rounded to 
irregular in outline, in irregular groups, yellowish green, 7-10 $\times 6-9 \mu \mathrm{m}$. Ascomata 3-10 aggregate into distinct pseudostromata, angular-rounded, immersed-erumpent, chroodiscoid, $0.8-1.2 \mathrm{~mm}$ diam., $0.1-0.15 \mathrm{~mm}$ high; disc exposed, thickly cream-white-pruinose; proper margin fused with thalline margin, forming numerous recurved, irregular to triangular lobes, sometimes falling off, internal with cream-white to pale yellowish surface. Excipulum entire, light yellow-brown, 20-30 $\mu \mathrm{m}$ wide, fused with thalline margin; columella absent; hypothecium prosoplectenchymatous, 10-15 $\mu \mathrm{m}$ high, pale yellowish; hymenium $80-100 \mu \mathrm{m}$ high, hyaline, clear; epithecium distinct, 15-25 $\mu \mathrm{m}$ high, grey-granular. Paraphyses unbranched, apically smooth; periphysoids present, 10-20 $\mu \mathrm{m}$ long; asci clavate to cylindrical, $80-90 \times 10-12 \mu \mathrm{m}$. Ascospores 8 per ascus, oblong-fusiform, 11-15-septate, $30-35 \times 7-8 \mu \mathrm{m}, 4-5$ times as long as wide, hyaline, distoseptate with more or less lens-shaped lumina, I-. Secondary chemistry: Stictic (major), constictic (submajor to minor), and cryptoctistic, hypostictic, and acetylhypoconstictic acids (minor to trace); ascomata and thallus $\mathrm{K}+$ yellow then orange, $\mathrm{P}+$ orange, microscopic section with $\mathrm{K}+$ persistently yellow efflux.

Remarks: This species is placed in the genus Pseudochapsa because of its agreement in several features, including chemistry and ascospore type, with P. phlyctidioides (Müll. Arg.) Parnmen, Lücking \& Lumbsch and related species. It differs from P. phlyctidioides in the endoperidermal thallus and the aggregate-pseudostromatic ascomata with thick, cream-white pruina, and the slightly larger ascospores. The only other ecorticate species with stictic acid and transversely septate ascospores, P. dilatata (Müll. Arg.) Parnmen, Lücking \& Lumbsch, has larger, angular to elongate ascomata and amyloid ascospores. Pseudochapsa albomaculata (Sipman) Parnmen, Lücking \& Lumbsch agrees with $P$. aptrootiana in the aggregate-pseudostromatic ascomata, but has an epiperidermal, greenish thallus, smaller ascospores, and constictic acid as predominant substance.

\section{Acknowledgements}

MESC thanks the CNPq (Conselho Nacional de Desenvolvimento Científico e Tecnológico) for a research grant (309058/2015-5), funding for the collecting trips in Sergipe (401186/2014-8), and a collaborative project with RL as Special Visiting Professor (314570/2014-4). FAPITEC (Fundação de Apoio à Pesquisa e a Inovação Tecnológica do Estado de Sergipe) is thanked for a student research grant to TAP. The study area map was produced using the "Aqui tem Mata?" online application, based on data from the "Atlas da Mata Atlântica", the Fundação SOS Mata Atlântica and the Instituto Nacional de Pesquisas Especiais (INPE).

\section{Author's Contributions}

MESC conceived the study. TAP, POP, and MESC carried out the field work and collection of specimens. TAP, POP, LAS, RL and MESC did the taxonomic studies, and TAP, POP and LAS wrote the species descriptions, under guidance by RL and MESC. TAP, POP, LAS, and RL created the images. All authors analyzed the available data on Atlantic rain forest fragments. MESC and RL wrote the draft manuscript and the final version was elaborated by all authors.

\section{Conflicts of interest}

The authors declares that they have no conflict of interest related to the publication of this manuscript.

\section{References}

BARNOSKY, A.D., MATZKE, N., TOMIYA, S., WOGAN, G.O., SWARTZ, B., QUENTAL, T.B., MARSHALL, C., MCGUIRE, J.L., LINDSEY, E.L., MAGUIRE, K.C. \& MERSEY, B. 2011. Has the Earth/'s sixth mass extinction already arrived? Nature 471: 51-57.
BROOKS, T. \& BALMFORD, A. 1996. Atlantic forest extinctions. Nature 380: 115.

CÁCERES, M.E.S. \& LÜCKING, R. 2013. Acanthothecis sarcographoides (Ascomycota: Graphidaceae), a morphologically unique, new lichen species in the Atlantic Rainforest of northeastern Brazil. Acta Bot. Bras. 27: 472-475.

CÁCERES, M.E.S., LÜCKING, R. \& RAMBOLD, G. 2008. Efficiency of sampling methods for accurate estimation of species richness of corticolous microlichens in the Atlantic rainforest of northeastern Brazil. Biodiv. Cons. 17: 1285-1301.

CÁCERES, M.E.S., APTROOT, A., PARNMEN, S. \& LÜCKING, R. 2014a Remarkable diversity of the lichen family Graphidaceae in the Amazon rain forest of Rondônia, Brazil. Phytotaxa 189: 87-136.

CÁCERES, M.E.S., LIMA, E.L., NASCIMENTO, A.A. \& LÜCKING, R. 2014b. Liquens brasileiros: novas descobertas evidenciam a riqueza no Norte e Nordeste do país. Bol. Mus. Biol. Mello Leitão 36: 101-119.

CÁCERES, M.E.S., APTROOT, A. \& LÜCKING, R. 2017. Lichen fungi in the Atlantic rain forest of Northeast Brazil: the relationship of species richness with habitat diversity and conservation status. Braz. J. Bot. 40: 145-156.

DAL FORNO, M. \& ELIASARO, S. 2010. Two new species of Graphidaceae (lichenized Ascomycota) from Brazil. Mycotaxon 112: 15-20.

DIRZO, R. \& RAVEN, P.H. 2003. Global state of biodiversity and loss. Ann. Rev. Environm. Res. 28: 137-167.

FEUERSTEIN, S.C., CUNHA-DIAS, I.P.R., APTROOT, A., ELIASARO, S. \& CÁCERES, M.E.S. 2014. Three new Diorygma (Graphidaceae) species from Brazil, with a revised world key. Lichenologist 46: 753-761.

FRISCH, A., KALB, K. \& GRUBE, M. 2006. Contributions towards a new systematics of the lichen family Thelotremataceae. Biblioth. Lichenol. 92: 1-539.

FUNDAÇÃO SOS MATA ATLÂNTICA \& INPE 2009. Atlas dos remanescentes florestais da Mata Atlântica e ecossistemas associados no período de 2000-2008. Relatório parcial, São Paulo.

FUNDAÇÃO SOS MATA ATLÂNTICA \& INPE 2015. Atlas da Mata Atlântica mostra situação do desmatamento em Sergipe. Relatório parcial, São Paulo.

FUNDAÇÃO SOS MATA ATLÂNTICA \& INPE. 2016. Atlas dos remanescentes florestais da Mata Atlântica no período de 2014-2015. Relatório técnico, São Paulo.

GALETTI, M., DONATTI, C.I., PIRES, A.S., GUIMARÃES, P.R. \& JORDANO, P. 2006. Seed survival and dispersal of an endemic Atlantic forest palm: the combined effects of defaunation and forest fragmentation. Bot. J. Linn. Soc. 151: 141-149.

GASWICK, W. \& LÜCKING, R. 2012. Key to the thelotremoid Graphidaceae, Version 1.0 (May 2012, 673 species). http://discern.uits.iu.edu:8780/admin/ temp/key_test5c_linear.html (accessed 17-11-2017).

GRADSTEIN, S.R., HIETZ, P., LÜCKING, R., LÜCKING, A., SIPMAN, H.J.M., VESTER, H.F.M., WOLF, J.H.D. \& GARDETTE, E. 1996. How to sample the epiphytic diversity of tropical rain forests. Ecotropica 2: 59-72.

GRAZZIOTIN, F.G., MONZEL, M., ECHEVERRIGARAY, S. \& BONATTO, S.L. 2006. Phylogeography of the Bothrops jararaca complex (Serpentes: Viperidae): past fragmentation and island colonization in the Brazilian Atlantic Forest. Mol. Ecol. 15: 3969-3982.

HALE, M.E. Jr. 1974. Morden-Smithsonian Expedition to Dominica: The lichens (Thelotremataceae). Smiths. Contr. Bot. 16: 1-46.

HALE, M.E. Jr. 1978. A revision of the lichen family Thelotremataceae in Panama. Smiths. Contr. Bot. 38: 1-60.

KÄFFER, M.I., CÁCERES, M.E.S., VARGAS, V.M.F. \& MARTINS, S.M.A. 2010 Novas ocorrências de liquens corticícolas crostosos para a região sul do Brasil. Acta Bot. Bras. 24: 948-951.

KÄFFER, M.I., MARTINS, S.M.A., CÁCERES, M.E.S. \& APTROOT, A. 2014 A new, locally common Graphis (Graphidaceae) species from southern Brazil. Cryptogamie, Mycol. 35: 233-237.

KALB, K., STAIGER, B. \& ELIX, J.A. 2004. A monograph of the lichen genus Diorygma - a first attempt. Symb. Bot. Upsal. 34(1): 133-181.

KOMPOSCH, H. \& HAFELLNER, J. 1999. List of lichenized fungi so far observed in the tropical lowland rain forest plot Surumoni (Venezuela, Estado Amazonas). Fritschiana 19: 1-10.

LEAKEY, R. \& LEWIN, R. 1995. The Sixth Extinction: Patterns of Life and the Future of Humankind. Doubleday, New York.

LÜCKING, R. 2014. A key to species of the Ocellularia papillata, perforata and terebrata morphodemes (Ascomycota: Graphidaceae). Glalia 6(3): 1-35. 
LÜCKING, R., ARCHER, A. W. \& APTROOT, A. 2009. A world-wide key to the genus Graphis (Ostropales: Graphidaceae). Lichenologist 41: 363-452.

LÜCKING, R., SEAVEY, F., COMMON, R.S., BEECHING, S.Q., BREUSS, O., BUCK, W.R., CRANE, L., HODGES, M., HODKINSON, B.P., LAY, E., LENDEMER, J.C., MCMULLIN, R.T., MERCADO-DÍAZ, J.A., NELSEN, M.P., RIVAS PLATA, E., SAFRANEK, W., SANDERS, W.B., SCHAEFER, H.P. JR. \& SEAVEY, J. 2011. The lichens of Fakahatchee Strand Preserve State Park, Florida: Proceedings from the 18th Tuckerman Workshop. Bull. Florida Mus. Nat. Hist., Biol. Sci. 49: 127-186.

LÜCKING, R., JOHNSTON, M.K., APTROOT, A., KRAICHAK, E., LENDEMER, J.C., BOONPRAGOB, K., CÁCERES, M.E.S., ERTZ, D., FERRARO, L.I., JIA, Z.F., KALB, K., MANGOLD, A., MANOCH, L., MERCADO-DÍAZ, J.A., MONCADA, B., MONGKOLSUK, P., PAPONG, K.B., PARNMEN, S., PELÁEZ, R.N., POENGSUNGNOEN, V., RIVAS PLATA, E., SAIPUNKAEW, W., SIPMAN, H.J.M., SUTJARITTURAKAN, J., VAN DEN BROECK, D., VON KONRAT, M., WEERAKOON, G. \& LUMBSCH, H.T. 2014. One hundred and seventy-five new species of Graphidaceae: closing the gap or a drop in the bucket? Phytotaxa 189: 7-38.

LÜCKING, R., MANGOLD, A. \& LUMBSCH, H.T. 2016. A worldwide key to species of the genera Myriotrema and Glaucotrema (lichenized Ascomycota: Graphidaceae), with a nomenclatural checklist of species published in Myriotrema. Herzogia 29: 493-513.

MANGOLD, A., MARTÍN, M.A., LÜCKING, R. \& LUMBSCH, H.T. 2008. Molecular phylogeny suggests synonymy of Thelotremataceae within Graphidaceae (Ascomycota: Ostropales). Taxon 57: 476-486.

MENEZES, A.A., LEITE, A.B.X., OTSUKA, A.Y. JESUS, L.S. \& CÁCERES, M.E.S. 2011. New records of crustose and microfoliose corticicolous lichens in Caatinga vegetation of the semi-arid region in Alagoas. Acta Bot. Bras. 25: 885-889.

MITTERMEIER, R.A., MYERS, N., THOMSEN, J.B., DA FONSECA, G.A. \& OLIVIERI, S. 1998. Biodiversity hotspots and major tropical wilderness areas: approaches to setting conservation priorities. Cons. Biol. 12: 516-520.

ORANGE, A., JAMES, P.W. \& WHITE, F.J. 2010. Microchemical Methods for the Identification of Lichens, 2nd Ed. British Lichen Society, London.

RANTA, P., BLOM, T.O.M., NIEMELA, J., JOENSUU, E. \& SIITONEN, M. 1998. The fragmented Atlantic rain forest of Brazil: size, shape and distribution of forest fragments. Biodiv. Cons. 7: 385-403.

RIBEIRO, M.C., METZGER, J.P., MARTENSEN, A.C., PONZONI, F.J. \& HIROTA, M.M. 2009. The Brazilian Atlantic Forest: How much is left, and how is the remaining forest distributed? Implications for conservation. Biol. Cons. 142: 1141-1153.

RIVAS PLATA, E. \& LÜCKING, R. 2013. High diversity of Graphidaceae (lichenized Ascomycota: Ostropales) in Amazonian Perú. Fung. Div. 58: 13-32.

RIVAS PLATA, E., LÜCKING, R. \& LUMBSCH, H.T. 2008. When family matters: an analysis of Thelotremataceae (Lichenized Ascomycota: Ostropales) as bioindicators of ecological continuity in tropical forests. Biodiv. Cons. 17: 1319-1351.
RIVAS PLATA, E., LÜCKING, R., SIPMAN, H.J.M., MANGOLD, A., KALB, K. \& LUMBSCH, H.T. 2010. A world-wide key to the thelotremoid Graphidaceae, excluding the Ocellularia-Myriotrema-Stegobolus clade. Lichenologist 42: 187-189.

RIVAS PLATA, E., LÜCKING, R. \& LUMBSCH, H.T. 2012. A new classification for the family Graphidaceae (Ascomycota: Lecanoromycetes: Ostropales). Fung. Div. 52: 107-121.

RIVAS PLATA, E., PARNMEN, S., STAIGER, B., MANGOLD, A., FRISCH, A., WEERAKOON, G., HERNÁNDEZ M., J.E., CÁCERES, M.E.S., KALB, K., SIPMAN, H.J.M., COMMON, R.S., NELSEN, M.P., LÜCKING, R. \& LUMBSCH, H.T. 2013. A molecular phylogeny of Graphidaceae (Ascomycota, Lecanoromycetes, Ostropales) including 428 species. MycoKeys 6: 55-94.

SEMARH 2012. Mata do Cipó vai se transformar em Unidade de Conservação. http:// www.semarh.se.gov.br/biodiversidade/modules/news/article.php?storyid=156 (accessed 17-11-2017).

SEMARH 2013. Refúgio de Vida Silvestre Mata do Junco receberá título de Posto Avançado da Reserva da Biosfera da Mata Atlântica. http://www.semarh.se.gov. $\mathrm{br} /$ modules/news/article.php?storyid=1606.

STAIGER, B. 2002. Die Flechtenfamilie Graphidaceae. Studien in Richtung einer natürlicheren Gliederung. Biblioth. Lichenol. 85: 1-526.

STAIGER, B., KALB, K. \& GRUBE, M. 2006. Phylogeny and phenotypic variation in the lichen family Graphidaceae (Ostropomycetidae, Ascomycota). Mycol. Res. 110: 765-772.

TABARELLI, M., MANTOVANI, W. \& PERES, C.A. 1999. Effects of habitat fragmentation on plant guild structure in the montane Atlantic forest of southeastern Brazil. Biol. Cons. 91: 119-127.

TABARELLI, M., AGUIAR, A.V., RIBEIRO, M.C., METZGER, J.P. \& PERES, C.A. 2010. Prospects for biodiversity conservation in the Atlantic Rainforest: lessons from aging human-modified landscapes. Biol. Cons. 143: 2328-2340.

UMBELINO, C.P. 2012. Mata do Cipó vai se transformar em unidade de conservação. 2012. Disponível em: http://www.agencia.se.gov.br/noticias/meio-ambiente/matado-cipo-vai-se-transformar-em-unidade-de-conservacao (accessed 17-11-2017).

UEZU, A., METZGER, J.P. \& VIELLIARD, J.M. 2005. Effects of structural and functional connectivity and patch size on the abundance of seven Atlantic Forest bird species. Biol. Cons. 123: 507-519.

WAKE, D.B. \& VREDENBURG, V.T. 2008. Are we in the midst of the sixth mass extinction? A view from the world of amphibians. Proc. Natl Acad. Sci. 105(Supplement 1): 11466-11473.
Received: 14/09/2017

Revised: 28/11/2017

Accepted: 10/12/2017

Published online: 05/03/2018 